Присутствие в растворе обоих ионов (хлор- и тиосульфат-) в концентрации 200 ме/л в одинаковой степени тормозит разложение 5 -метилрезорцина $\left(k / k_{0}=0,86\right)$. Увеличение концентрации этих минеральных добавок до 500 ма/ $\Omega$ усиливает их тормозящее действие $\left(k / k_{0}=0,47\right)$. т. е. в два раза снижается скорость биоокисления орцина, типичного представителя сланцевых фенолов.

Приведенные результаты свидетельствуют о сложном механизме действия неорганических примесей на процесс биохимического окисления фенолов.

\title{
ЛИТЕРАТУРА
}

1. Тюрксон Х., Метсик Р., Халлинг А., Бюл. Сланцевая и хим. промышленность, № 4, 34 (1965).

2. Берновская Н., Губе ргриц М., Кирсо У., Изв. АН ЭССР, Хим. Геол., 20, 21 (1971).

3. Берновская Н., Кирсо У., Губергриц М., Изв. АН әССР, Хим. Геол., 20, 216 (1971).

Ннститут химии АН ЭССР

Таллинский политехнический институт

Поступила в редакцию 16/III 1972

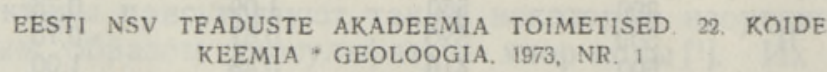

ИЗВЕСТИЯ АКАДЕМИИ НАУК ЭСТОНСКОИ ССР. ТОМ 22 ХИМИЯ - ГЕОЛОГИЯ. 1973, № 1

\section{ДЕГИДРИРОВАНИЕ Н-ДОДЕКАНА НА ПЛАТИНОВОМ КАТАЛИЗАТОРЕ}

N. ZLOBIN. NORMAALDODEKAANI DEHUDREERIMINE PLAATINAKATALUSAATORITEL

N. ZLOBIN. DIE DEHYDROGENISATION VON $n$-DODEKAN AN PLATINKATALYSATOREN

В предыдущем сообщении ['] приведены методика и результаты исследования процесса парофазного дегидрирования $н$-октана на алюмоплатиновом катализаторе при варьировании температуры и длительности контакта фаз (протяженности слоя катализатора).

Поскольку изменение размеров молекулы алкана, подвергаемого дегидрированию, может повлиять на оптимальные условия ведения процесса и его конечные результаты, то на втором этапе были изучены аналогичные превращения с использованием той же методики для $\boldsymbol{H}$-додекана. Результаты этой работы сжато изложены в настоящем сообщении.

На рис. 1 и 2 приводятся кривые зависимости выхода $\mu$-додеценов от температуры и протяженности слоя при различном содержании платины в составе катализатора. Для кривых в подавляющем большинстве случаев характерно наличие некоторого максимума, который отвечает температуре $360-380^{\circ} \mathrm{C}$. Наибольший выход додеценов - 25 вес. \% - отмечается при использовании катализатора сравнительно невысокой актив- 


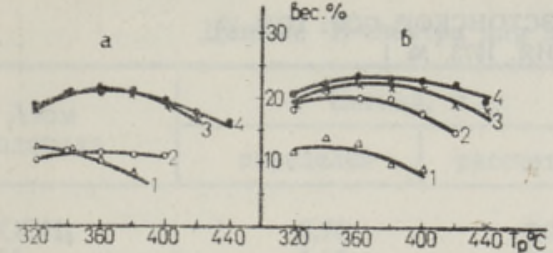

Рис. 1. Выход додеценов в процессе дегидрирования н-додекана при повышенном содержании платины в катализаторе.

Содержание платины: $a-2,5$ вес. $\%$, $6-1,0$ вес. $\%$.

Длина слоя $(L): 1-6 \mathrm{cM}, 2-3 \mathrm{~cm}$, $3-2 \mathrm{CM}, 4-1 \mathrm{CM}$.

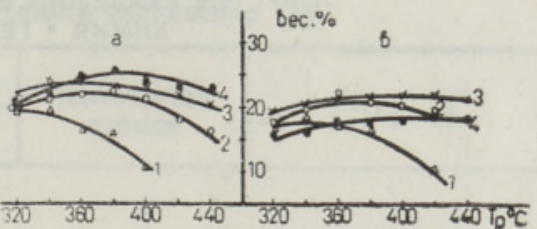

Рис. 2. Выход додеценов от исходного углеводорода при пониженном содержанин активного компонента в катализаторе.

Содержание платины: $a-0,5$ вес. \%, $6-0,25$ вес. $\%$.

Обозначение кривых см. на рис. 1.

ности $\left(0,5 \% \mathrm{Pt} \mathrm{Al}_{2} \mathrm{O}_{3}\right)$ и с минимальной протяженностью слоя ( $L-2,0$ и 1,0 cm). Селективность процесса, отвечающая этому выходу, достигает примерно $80 \%$. Напомним, что максимальный выход октенов достигается при использовании того же катализатора $(L-2,0$ c. и и температура реактора $\left.\left(\mathrm{T}_{\mathrm{p}}\right) 400^{\circ}\right)$, причем выход октенов оказывается примерно в полтора раза ниже - $16 \%\left[{ }^{1}\right]$. Аналогичная тенденция отмечена также в $\left.{ }^{2}\right]$ при дегидрировании алканов на цинкхромовом катализаторе в проточном режиме. Общие же закономерности, управляющие изучаемым процессом дегидрирования и описанные нами ранее, остаются в силе.

В продуктах деструкции $н$-додекана методом ввода эталонных веществ и по индексам удерживания [3] обнаружены $\boldsymbol{H}$-парафины с меньшей молекулярной массой. Содержание в катализате суммы парафинов ряда $H$-октан - $H$-ундекан изменяется от близкого к нулю в мягких условиях $\left(0,5-0,25 \%\right.$ Pt $\mathrm{Al}_{2} \mathrm{O}_{3}, \mathrm{~T}_{\mathrm{p}} 380^{\circ}$ и $\left.L-1,0-2,0 \mathrm{cM}\right)$ до $11 \%$ при сравнительно жестком режиме $\left(2,5 \% \mathrm{Pt}^{-} \mathrm{Al}_{2} \mathrm{O}_{3}, \mathrm{~T}_{\mathrm{D}} 380^{\circ}, L-6,0 \mathrm{~cm}\right)$. В продуктах деструкции $н$-додекана обнаружены также соответствующие олефины, но в незначительных количествах. Выход ароматических углеводородов неизменно возрастает с повышением температуры и снижается с уменьшением доли платины в катализаторе и протяженности слоя. Так, в охарактеризованных выше сравнительно жестких условиях он составляет $20,8 \%$ от выхода катализата, а при смягченном режиме ( $\mathrm{T}_{\mathrm{p}} 380^{2}$, содержание $\mathrm{Pt}-0,25 \%$ и $L-1,0 \mathrm{~cm})$ в составе продуктов удается обнаружить лишь их следы. При этом, наряду с легкими ароматическими углеводородами, в катализате обнаружен $\boldsymbol{H}$-гексилбензол и некоторые другие алкилбензолы. Соединений нафталинового ряда обнаружить не удалось, хотя, вероятно, возможно их формирование [ $\left.{ }^{4}\right]$.

\section{ЛИТЕРАТ У РА}

1. З ло б и н Н., Изв. АН ЭССР, Хим. Геол., 20, 309 (1970).

2. Сергиенко С. Р., Медведева В. Д., Петрова А. А., Чирова Е. В., Изв. АН Туркм. ССР. Сер. ФТХ и ГН, № 5, 61 (1964).

3. Э й з ен О., И в а н ов А., Изв. АН ЭССР, Хим. Геол., 19, 297 (1970).

4. Долгов Б. Н., Катализ в органической химии, Л., 1959, с. 280 и 276.

Институт химии

Академии наук Эстонской ССР
Поступила в редакцию 6/IV 1972 